\title{
An Explorative Study on Ecological Designs of the Landscape of River Channels
}

\author{
$\operatorname{Man} \mathrm{Lu}^{12}$ \\ 1 School of Architecture \\ Southeast University \\ Nanjing, China \\ Email: mmmm0526@sina.com
}

\author{
Wang Chuanyue ${ }^{2}$ \\ 2 School of Civil Transportation \\ Hohai University \\ Nanjing, China \\ Email: wangchuanyue09@sina.com
}

\begin{abstract}
As urbanization accelerates in China, the construction of urban river channel receives increasing attention. The problem is how to effectively apply the principle of ecological design in river channel landscape designs so that ecological landscape design can be put into practice and gradually become a design trend. This paper studies the concept and principles of ecological river landscape design and its application in actual construction in hopes of exploring workable urban ecological landscape design methods and related theory in line with China's modern urban development requirements.
\end{abstract}

Key words - Urban river channel, landscape, ecological design

\section{INTRODUCTION}

Over a long time, people, river channels are managed only to achieve the basic functions of flood prevention while ignoring its ecological role, which leads to deteriorating river channel ecological environment. Compared with other countries, our country attaches importance to irrigation function of river channels but paid little attention to ecological environment construction. Recently with the increasing awareness of the importance of ecological balance and environment protection, the concept of ecological treatment of river channel gradually receives more attention. The treatment of river channel environment expands from mere treating water pollution to recovering ecological environment, wetland and ecological construction. However, the landscape design that integrates river channel treatment and landscape design remains at the experimenting stage. The article seeks to explore the application of urban river channel landscape design in real projects through real engineering examples.

\section{THE CONCEPT OF URBAN RIVER CHANNEL LANDSCAPE ECOLOGY}

\section{A. Current Status and Problems of urban river channel landscape design}

1) The Reduction, Straightening and Channelization of River Channels

The reduction, straightening and channelization of river channels destructs the original natural landscape and ecological balance of the river, undermines living environment of plants and animals, reduces biodiversity and threatens ecological stability. Faster water flow aggravates the erosion of river bed bottom and revetment, reduces the supply of underground water and lowers the permeability of river banks, leading to river' reduced capacity of adjusting its water storage. In addition, potential safety problems arising from vertical and steep river banks keep people away from getting close to water.

2) Over Development of Riparian Areas and Deteriorating Water Quality

It cannot be denied that many cities have realized the importance of the river body thus carried out river purification. The sound landscape of some transformed riparian areas attracts many economic groups to conduct land development. Overly tall and dense buildings along the banks not only hinder free air flows but also endanger recently recovered natural ecological environment. Lands for various commercial purposes take up space reserved for river, reducing the cross section of the river, adding extra difficulty to flood control in cities as it severely affects flood passage [1]. With increased riverside population density, industrial production and life activities have growing impact on river channels. A large amount of waste water from production and domestic usage is discharged directly into rivers, causing water pollution, deterioration of water quality and damaged river ecological environment. Household garbage scattered in the river shore causes water, air and soil pollution. Especially during monsoon seasons, expanded areas with pollutants floating on the surface seriously affect ecological balance and landscape value of riparian areas.

\section{B. Categories of River Channel Landscape}

River channel refers to the integration of river body, sandbars, beaches and water between river shorelines. As the core of the river, it consists of three parts including river bed, beach and river terraces. Landscape refers to the combination of natural elements and cultural phenomena, the total of sights seen from specific locations [2]. Therefore, landscape of river channel is not constituted by rivers alone but centers on rivers with land area in its radiance also included.

Landscape design emphasizes integrating local 
characteristics and enhancing aesthetic sense of beauty. Landscape as part of the ecological system is expected to support the ecological system. Concepts in landscape ecology include the famous "4R" principles that "Reduce, Reuse, Recycling and Renewable". River landscape studied in this research mainly refers to landscapes of the river channel, buffer zone and the entire river bank. "Any design that seeks to comply with ecological processes and reduce the impact on the environment to the minimum can be called ecological designSimon • Fan • Di Ryan [3]. The so called ecological landscape design refers to the design based on the theories on modern landscape ecology to construct a landscape with ecological, aesthetic and recreation functions through a series of landscape ecology design techniques so as to realize harmonious coexistence between humans and nature and sustainable development of human society.

\section{DESIGN PRINCIPLES OF URBAN RIVER CHANNELS LANDSCAPE}

\section{A. Design Principles of Imitating Nature}

The concept of imitating nature originated from western countries. European and American countries have realized industrialization and urbanization as early as in the 19th century. River channel management already reached a medium level by then before gradually advanced into higher stages of "ecologic irrigation" or "environment irrigation". The goal of most river ecologic system management is to maintain the ecologic integrity of rivers, which demands the abandonment of the concept of "speed oriented" river system treatment, respect for rules of nature, evaluation of recovery and protection of natural environment and ecology so as to fully exert comprehensive functios.

Guided by theories on ecology system, the design seeks to integrate with nature and imitate nature. Take living environment of plants and animals into full consideration when constructing revetments for flood prevention and discharge by drawing inspiration from nature. Realize harmonious coexistence between humans and nature through integrating artificial buildings with nature [4].

\section{B. Design Principle of Localization}

Research current situation of local vegetation and its natural attributes to make sure the design is suitable for local natural and geographical conditions and reflect local landscape characteristics. The design is not about to repeat popular forms and materials at will but adjust to local landscapes, climate, soil, labor and other conditions. The design employs local materials and vegetation thus costs low, reflects local landscape characteristics and helps sustain ecological environment.

\section{Design Principle of Protection}

Design that imitates nature in form does not necessarily serve ecological purposes. The significance of protective design lies in that it takes the lead in combining ecological studies with landscape designs. It scientifically analyzes local ecological factors and relations, protects the existing ecological system to the full through appropriate design techniques, reduces negative impact on natural environment and stipulates design ethics: limit harms to nature by humans who should take the responsibility of protecting nature since humans are an organic part of it.

\section{Design Principle of Restoration}

With the development of ecology and environmental ecology, scientists in the 1990s from the United States, Germany and other countries proposed improving polluted environment through self-organization and self-regulating of natural ecosystem itself in combination with selecting special plans and microorganisms to help ecological system to pollutants degradation. This technology is called that of environmental ecological restoration [5]. Various scientific measures are taken in river channel landscape designs to recover damaged ecological environment and repair the original urban structures through landscaping to realize balanced interests between ecological environment and human society and promote sound development of all urban systems.

\section{EXPLORATION OF URBAN RIVER LANDSCAPE ECO-DESIGN PRACTICES}

Study the rules and principles of evolutionary processes occurring within the ecological landscape system under the guidance of ecological design principles. Apply theories to technologic measures that are practiced in landscaping project of Jiangdongzhi River of Zhejiang Province to explore means to better utilize, protect and improve landscape.

\section{A. Enhancing Connection among Water Systems in Overall Designs}

Carry out an overall plan in light of natural attributes of river channels and current satiation of roads and residential houses. Connect green land in waterfront areas with the surrounding buildings in a coherent manner in compliance with both the overall and local environment. Reconstruct river shorelines and build rhythmic pattern of landscape sites in order to create nature-based river channel landscape. Realize the connecting function of natural rivers to provide space for species movement so that the species that were forced to live in isolation can survive and propagate [6]. It also provides urban residents space for recreation and leisure activities by increasing the ecological environment and air quality of surrounding areas.

\section{B. Eco-Design of Revetment}

Ecologic embankment refers to a new form of embankment that protets the slopes along river channel thrugh the integration of plants with civil engineering or the usage of plants alone. Since ecological embankment can fulfill the functions of flood prevention, ecologic complement, landscape contribution and self purification, it gradually recives more and more attention and is expected to represent the development trend of future embankments. 
The soil covering the river bed of Jiangdongzhi River contains high percentage of sand thus is poor in cohesion, which subjects riverbanks to water erosion leading to soil and water loss and even bank collapse. Therefore, we adopte appropriate eco-friendly revetment design technologies according to different situations in different parts of river banks :(1) Eco-bag revetment: functions as a filter that permeates water and holds the soil; it can prevent the loss of nutrients and water without compromising the normal exchange of water within the soil so that water needed for plants growth can be maintained and furnished in time; it is also plant- friendly as plants can achieve free growth through the bag while their roots enter the foundational soil just like numerous anchors further consolidating the bag and the main revetment body, which realizes the goal of building permanently stable slopes and reducing maintenance costs.(2) Fish bag brick revetment: it is categorized as embedded earth blocks that provides growing space for aquatic plants and purify water; gap between bricks and plants that have grown together form natural fish nests, strengthening river ecological balance; bricks, plants and fish constitute enjoyable landscape; permeable bags ensure exchange of water between riverbanks and river body which can also hold off flood to an extent.(3) Geotechnical material revetment: adopts the technology of geotechnical net mat that helps reinforce and culture the soil; it is composed of netted mat, soil, plant seeds and etc; the net mat is loose and tough, containing enough space that can be filled with sand gravels and soil. The roots of the plants can grow through the holes in the net and grown turf can make netted mat, turf and soil stick together. Geotechnical embankment features strong anti-erosion ability, integrity, and flexible application. Being porous, it can achieve ecological purpose and provide living space for aquatic plants, animals and micro-organisms. (4) Bamboo stakes revetment: in areas where vegetation is well preserved, no expansion of river channels should be conducted and preserve the original natural ecological systems that is composed of grassland, trees, shrubs as well as plants that can absorb water and aquatic ones. In the mean time, to maintain the stability of soil on the slope after dredging, employs environment-friendly raw materials at the foot of the slope including local bamboo and wood to reduce bank erosion, improves the habitat environment of aquatic flora and fauna and significantly reduces construction costs. (Fig. 1 to 4 ).

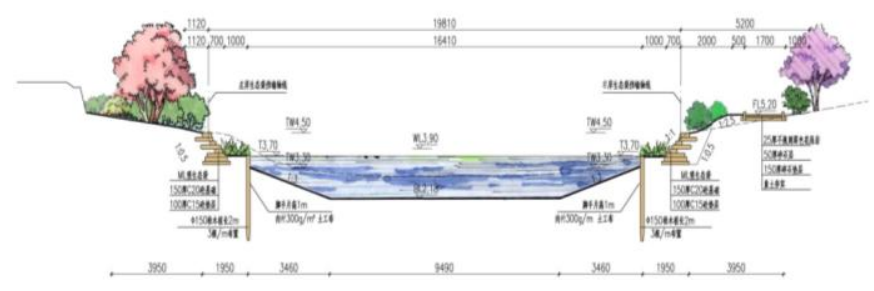

Figure.1. Eco-bag revetment profile

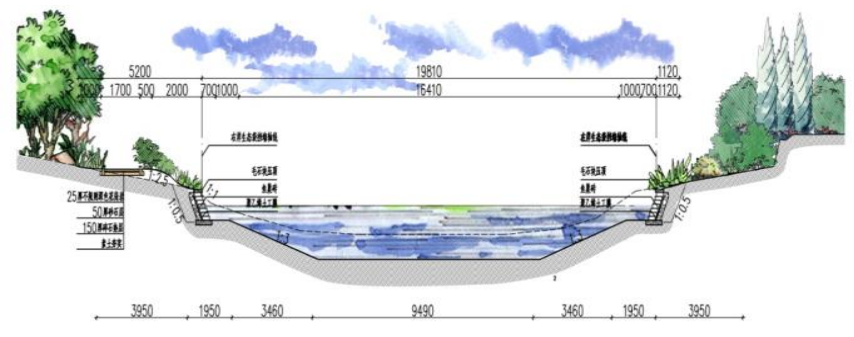

Figure.2. Fish bag brick revetment profile

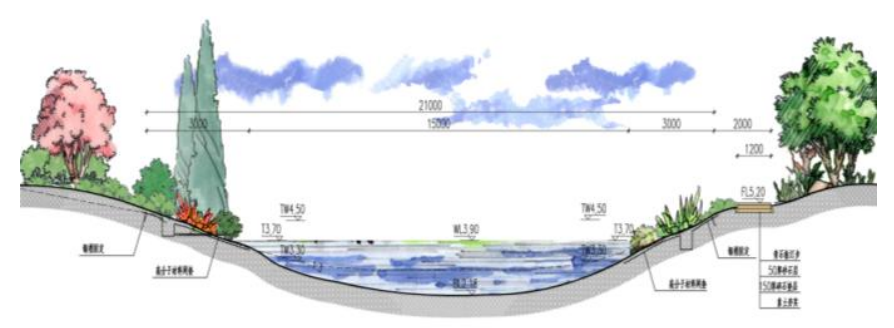

Figure.3. Geotechnical material revetment profile

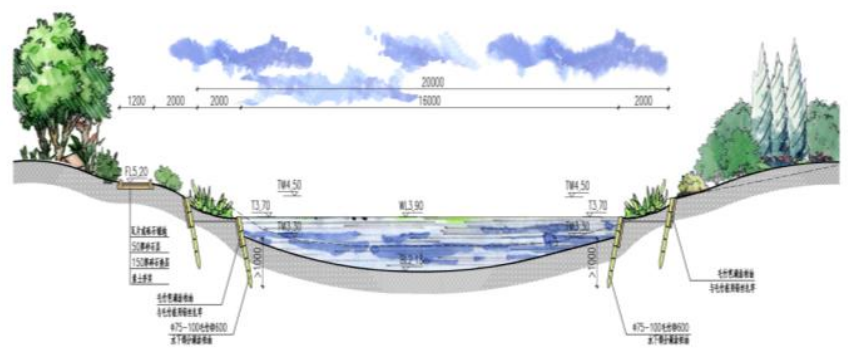

Figure.4. Bamboo stakes profile

\section{Selection of Plants Beneficial to Ecological Recovery}

Vegetation recovery should seek after reconstructing native plant communities in river channels and the surrounding area based on the principle of natural succession to create natural floristic landscape. Grow aquatic plants living below water such as Hydrilla verticillata at the bottom of the river, aquatic plants that float above water such as water lily at the surface, wetland plants such as calamus on the river banks. In this way, plant communities featuring varied plant zones "aquatic - marsh - wet - mesophyte plants" can be formed. These plants can hold soil and water and purify water while they grow up and ultimately into stable waterfront floristic communities, which greatly enhance biological profits. Before growing plants, carry out research on vegetation in local areas, taking landscape, safety, ecological balance as well as the suitability for surrounding environment into full consideration and select plants using strict criteria:(1) plants suitable for local climate and meteorological conditions; (2) low requirements for soil conditions, (3) local breeds; (4) resilient against pesticides and diseases; (5) plants can live long or their effects can last long; (6) plants that can beatify the environment; (6) easy to maintain and manage; (8) marketability.Hangzhou's climate is monsoon subtropical with four distinctive seasons. It has climate characteristics of both the ocean and continents. Plants are selected mainly from local 
ones. The target region features sandy soil that is poor in water retention and strong in water supply and has little nutrients contained within hence is poor in preserving soil and strong in soil supply. It has excellent air permeability, poor caking value and great suitability for farming. Plant species resistant to aridity and locally ones are recommended to be grown including elm, cypress, Zhejiang camphor, sassafras tzumu, Zhejiang nanmu, ailanthus and etc. In addition, it should be taken into consideration that human behavior plays a role in shaping plants environment. Walking, resting and watching all demand corresponding space arrangement. According to requirements from landscape creation, artificial environment is created through combination of plants according to their growth habits. Under the premise of unified keynote, various plants are employed to bring out characteristic scenery of each season. Create tree shade through building plant community featuring multi-layers and divide space by growing plants in light of topography.

\section{Employment of Ecological Design Techniques in Buildings design on Waterfront Space}

River channel is open public space of a city. Therefore river channels constitute landscapes characteristic of local areas together with buildings on both sides. After understanding buildings along the banks of Zhi River, keep part of the buildings while renovating the others. Remove buildings that severely damages or demands too high cost to renovate. For aged and old buildings that can still be reused, employ local materials such as blue bricks and bamboo so as to better integrate buildings along the banks with river channel landscape and cut down economic and energy waste from transportation.

As the driving force and central power of building the city--the artificial ecological system, humans must take closeness with water into consideration when designing ecological river channel landscape. We can build platforms for getting close to water in light of the variance of heights of river beds, ecological revetments and different levels of submerged revetments so as to integrate constructions with river channels. In the dull space that residents are reluctant to go to due to residential habits, poor light, strong wind and difficult environmental management, establish necessary facilities for leisure activities and human interactions. Such places should be tidy, comfortable, beautiful and spacious so as to attract residents to come and have activities of their wishes and promote exchanges between each other. In this way, the dull space is transformed into vibrant space to build a green ecological corridor that provides ways of approaching water

\section{CONCLUSIONS}

During its development, cities are constantly changing according to external factors and internal needs. Even as it maintains general stability of spatial structures, minor local changes have never stopped. If we interpret landscape design as a process of analyzing conditions of outdoor space and land, offering corresponding solutions and supervising the execution of the solution, then the responsibility of the landscape designer is to help create a harmonious environment in which humans, building, communities, the city can coexist. Therefore landscape design is an ecologic design of outdoor space and land in nature with ecological principles as its core. To put it in depth, landscape design is the design of human ecologic system that relies on natural force to the maximum as well as a design based on nature's self regenerating ability. As water is the source of life, humans have inborn desire for being close to water.

Through this practice of river channel landscape design, the author suggests: (1) Unify understanding and strengthen theoretical study on ecological landscape design. (2) Adopt designs that promote gradual and sustainable development to prevent rushed projects whose glamour can only last for a short time. Landscape is expected to not only satisfy people's visual enjoyment and desire for being in close contact with water but more importantly to build artificial ecology in compliance with the rule of nature. (3) River channel landscape design should be able to evoke residents' sense of belonging so that they can evaluate local ecological environment protection out of self awareness. (4)Urban river channel landscaping belongs to public service industry. Financial balance between income and expenditure is the necessary requirement of the maintenance and development of urban landscape and the main indicator of economic benefits. Therefore, we can adopt economic theories on cost benefit and measure economic interests of river landscape from the angles of investment and economic return so as to avoid over design.

The treatment of river channels has developed as the combination of ecology, landscaping and other disciplines. This suggests that it is necessary to respect biodiversity, reduce exploitation of resources, maintain sound nutrition and water cycle, maintain qualified living environment for plants and animals when designing landscape to improve living environment for humans and the health of the ecological system. The above are precisely the connotations of ecological landscape designs. Only through transforming river channel landscape on the basis of abiding by natural development principles so that the landscape integrates science with art can river landscape create impressive turnouts and serve pleasant space for humans to live.

\section{REFERENCES}

[1]. Zhu Guoping, Xu Wei, Qi Shi, Yang Hailong and Zhou Lijun, "An explorative study on the treatment and ecological design of river channels of Chengdong River of Zhaoyuan City of Shandong Province," J.vol.3,pp.160-162,2004.

[2]. Hamerton Philip, Landscape. Boston:Roberts, 1885.

[3]. Kongjian Yu, Li Dihua and Ji Qingping, "Eecological design of landscape and the ciity: Concepts and Principles," J Chinese garden, vol.6.pp. 3-7,2001.

[4]. DA Liangjun and Yan Jingsong, "Exploration of recovery of natural water systems and building artificial waterscape in the city,” J.Study on modern cities, vol.1,pp. 10-11, 2010.

[5]. Ren Gang, "Analysis of technologies of ecological landscape designs," D, Harbin: Harbin Industrial University,2010.

[6]. Liu Xiaotao, "An explorative study on some problems in treating urban rivers," J. Designer,vol.6, pp. 66-69, 2001 